\title{
Regulation of mineralisation in bone and vascular tissue: a comparative review
}

\author{
Lucie E Bourne, Caroline PD Wheeler-Jones and Isabel R Orriss \\ Department of Comparative Biomedical Sciences, Royal Veterinary College, London, UK \\ Correspondence should be addressed to I R Orriss: iorriss@rvc.ac.uk
}

\begin{abstract}
Biomineralisation, the deposition of mineral onto a matrix, can be both a physiological and pathological process. Bone formation involves the secretion of an extracellular matrix (ECM) by osteoblasts and subsequent mineralisation of that matrix. It is regulated by a number of local and systemic factors and is necessary for maintenance of normal bone health. Conversely, mineralisation (or calcification) of soft tissues, including the vasculature, is detrimental to that tissue, leading to diseases such as arterial medial calcification (AMC). The mechanisms underlying AMC development are not fully defined, though it is thought that vascular smooth muscle cells (VSMCs) drive this complex, cellmediated process. Similarly, AMC is regulated by a variety of enzymes and molecules, many of which have already been implicated in the regulation of bone mineralisation. This review will provide an overview of the similar, and sometimes opposing effects of these signalling molecules on the regulation of bone mineralisation and AMC.
\end{abstract}

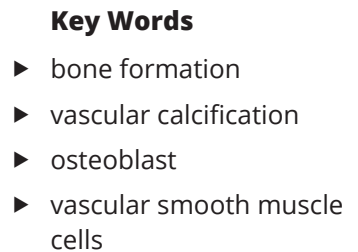

Journal of Endocrinology (2021) 248, R51-R65

\section{Introduction}

Biomineralisaton is considered to be the deposition of mineral in an organised manner onto a matrix (Boskey 1998). In living tissues this can be either a physiological or a pathological process. The skeleton is characterised by its mineralised composition, a property that is vital for its structure and function. Conversely, the deposition of mineral in soft tissues is often pathological and usually detrimental to the function of that tissue. The mineralisation (or calcification) of the vasculature is particularly damaging as it is associated with an increased risk of adverse cardiovascular events (Hutcheson et al. 2017). At present there are no effective therapeutic options that can prevent or regress vascular calcification.

In journal articles, the terms 'calcification' and 'mineralisation' are used interchangeably. Nonetheless, mineralisation is most often used in the context of bone and refers to the process of laying down minerals within an extracellular matrix (ECM). Calcification, by definition, refers to the accumulation of calcium salts in a tissue and this is a commonly used term to describe the pathological processes occurring in soft tissues (Orriss 2020). This review compares the processes of physiological bone formation and pathological vascular calcification, and provides an overview of how these can be regulated by local and systemic factors.

\section{Bone formation}

Bone is a composite tissue comprised of both organic and mineral components, specialised cells and water. As a result, bone formation is a two-step process and begins with synthesis and deposition of the ECM (also known as osteoid) followed by mineralisation. The ECM is formed primarily of type I collagen ( 90\%) along with non-collagenous proteins, growth factors 
and glycoproteins. The mineral component of bone is hydroxyapatite $\left(\mathrm{Ca}_{10}\left(\mathrm{PO}_{4}\right)_{6}\left(\mathrm{OH}_{2}\right)\right)$ which is formed from inorganic phosphate $\left(\mathrm{PO}_{4}^{3-}\right.$ or $\left.\mathrm{P}_{\mathrm{i}}\right)$ and calcium $\left(\mathrm{Ca}^{2+}\right)$ ions. Osteoblasts, which are derived from mesenchymal stromal cells (MSCs), are responsible for bone formation. Due to the large number of ECM proteins they synthesise and export, osteoblasts contain a large golgi apparatus, secretory vesicles and abundant rough endoplasmic reticulum and mitochondria (Dudley \& Spiro 1961).

\section{Bone mineralisation: how does it occur?}

Bone mineralisation is essential for maintaining the stiffness and rigidity of bone but despite decades of research the exact mechanisms by which mineralisation occurs remains an area of debate. Currently, there are two main theories, matrix vesicle-mediated and collagen template, though other processes may also contribute to mineralisation. Matrix vesicles (MVs) are a small (100$200 \mathrm{~nm}$ ), specialised form of extracellular vesicle that are secreted into the osteoid by osteoblasts to facilitate mineralisation (Anderson 2003). The concept of MVs was first proposed in the late 1960s following independent work by Anderson and Bonnucci which discovered that nanoparticles were involved in mineralisation (Bonucci 1967). The contents of MVs include $\mathrm{Ca}^{2+}$ and $\mathrm{P}_{\mathrm{i}}$ ions, enzymes, lipids and miRNAs (Anderson 1969, Cui et al. 2016). The accumulation of $\mathrm{Ca}^{2+}$ and $\mathrm{P}_{\mathrm{i}}$ within the MV, via the actions of phosphatases and transporters, is thought to increase the concentration of these ions enough to begin the initial phase of mineralisation. To begin with, these ions combine to produce an octacalcium-phosphate intermediate prior to the formation of hydroxyapatite (Anderson 1969). The continuing growth of the hydroxyapatite crystals within the MV will eventually lead to membrane rupture and release of the crystals into the extracellular environment. Subsequent growth of the hydroxyapatite crystals is then dependent on the extracellular concentrations of $\mathrm{Ca}^{2+}$ and $\mathrm{P}_{\mathrm{i}}$ and on the levels of local mineralisation inhibitors (Anderson 1969, Cui et al. 2016).

The theory of collagen template-mediated mineralisation was first suggested in the early 1990s (Landis et al. 1993). This idea proposes that the $40 \mathrm{~nm}$ hole regions within the collagen fibrils allow $\mathrm{Ca}^{2+}$ and $\mathrm{P}_{\mathrm{i}}$ to accumulate, precipitate and form hydroxyapatite crystals (Landis et al. 1993). The structure and assembly of the collagen fibres then dictates the subsequent crystal growth. Whilst there is evidence to support both theories, it remains unclear which of these mechanisms is primarily responsible for the initiation and propagation of hydroxyapatite formation. However, the end result is the same, a mineralised bone matrix. Furthermore, it is likely that these two processes of mineralisation are not mutually exclusive. Whilst it is possible that they could both occur at the same time, no conclusive evidence appears to suggest that this is the case.

One complication is that it appears highly unlikely that hydroxyapatite released from MVs is able to navigate its way into the specific hole regions of the collagen fibril unaided, after bursting open the MV. As with many techniques that study processes at the nanoscale, artefactual evidence of hydroxyapatite mineral in MVs may be as result of specimen preparation for electron microscopy. Amorphous calcium phosphate (ACP) is thermodynamically unstable, its stabilisation is controlled by $\mathrm{pH}$ and is solution-mediated, which is likely to result in conversion to the more stable crystalline hydroxyapatite after chemical fixation (Boskey \& Posner 1973). More recently it was proposed that MVs released from osteoblasts during mineralisation contain an ACP precursor that is transported to the hole region of the collagen fibril (Boonrungsiman et al. 2012). Nucleation sites within the gap region initiate crystallisation and allow crystal growth to spread along the fibril surface. The finding that ACPs are a precursor to the formation of mature hydroxyapatite has been supported by several studies (Mahamid et al. 2008, Dey et al. 2010, Nudelman et al. 2010, Mahamid et al. 2010). Lotsari et al. suggested that deposited ACP granules undergo a step growth which enables the ACP precursors to crystallise and form apatite platelets (Lotsari et al. 2018). However, it remains unclear how MVs spatially recognise where to transport their contents to ensure that hydroxyapatite formation occurs.

Other studies have eluded to the presence of mineral in the interfibrillar compartment and therefore outside of the collagen fibrils, suggesting alternative theories of bone structure and subsequently, mineralisation (McNally et al. 2012, 2013, Schwarcz et al. 2020). For example, processes including (1) mineral growth beyond the gap regions along the fibril, (2) growth between the fibrils and, (3) growth external to the fibrils have all been proposed. All of which would ultimately require different mechanisms (Landis et al. 1993, Lees et al. 1994, Prostak \& Lees 1996, Su et al. 2003, Nudelman et al. 2010, Silver \& Landis 2011, McNally et al. 2012). Together, evidence from the literature presents a complex and currently incomplete understanding of the process of bone mineralisation. 


\section{Regulation of bone mineralisation}

The process of bone mineralisation is tightly regulated by a variety of local and systemic factors. The coordinated action of these prevents hypo- or hypermineralisation, both of which are detrimental to skeletal function. Some of the key regulators of bone mineralisation are described subsequently (Fig. 1).

\section{Pyrophosphate $\left(\mathrm{PP}_{\mathrm{i}}\right)$}

The key role of $\mathrm{PP}_{\mathrm{i}}$ as a local inhibitor of mineralisation was first discovered by the seminal work of Fleisch and colleagues in the 1960s (Fleisch \& Bisaz 1962a, Fleisch \& Bisaz 1962b). Extracellular $\mathrm{PP}_{\mathrm{i}}$ potently inhibits the ability of $\mathrm{Ca}^{2+}$ to crystallise with $\mathrm{P}_{\mathrm{i}}$ to form hydroxyapatite; it also binds strongly to the surface of hydroxyapatite and prevents further crystal growth (Fleisch \& Bisaz 1962a, Fleisch \& Bisaz 1962b, Fleisch et al. 1966). This initial work has helped to establish the idea that $\mathrm{PP}_{\mathrm{i}}$ acts as the body's 'water softener' and acts locally to control mineralisation processes (Orriss 2020).

\section{Ecto-nucleotides pyrophosphatases/ phosphodiesterases (NPPs)}

The NPP family of enzymes primarily hydrolyse the phosphodiester bond in nucleotide triphosphates (e.g. ATP, UTP) to generate $\mathrm{PP}_{\mathrm{i}}$ and the corresponding monophosphate. Of the seven members of the NPP family, it is NPP1 which has been shown to be particularly important in bone (Hessle et al. 2002, Mackenzie et al. 2012). NPP1 knockout mice (Enpp1--) have reduced extracellular $\mathrm{PP}_{\mathrm{i}}$ levels and display aberrant calcification of the spine, joints, tendons and other collagen-rich soft tissues (Hessle et al. 2002, Johnson et al. 2003, Mackenzie et al. 2012, Hajjawi et al. 2014). Enpp1\% animals also display reduced trabecular and cortical bone; the cause of this surprising observation is unclear but it could be a consequence of reduced mobility and/or defects in other tissues (Mackenzie et al. 2012, Hajjawi et al. 2014).

\section{Tissue non-specific alkaline phosphatase (TNSALP)}

TNSALP is the form of alkaline phosphatase that is found in the bone, liver and kidney. It is a broad spectrum ectonucleotidase that can hydrolyse numerous phosphate containing molecules including $\mathrm{PP}_{\mathrm{i}}$ (Zimmermann et al. 2012). The ability of TNSALP to hydrolyse $\mathrm{PP}_{\mathrm{i}}$ to generate $\mathrm{P}_{\mathrm{i}}$ means that it plays a central role in driving bone mineralisation (Millan 2013). In keeping with this function, TNSALP knockout mice have skeletal deformities, defective bone mineralisation and die before weaning of epileptic seizures (Waymire et al. 1995, Narisawa et al. 1997, Fedde et al. 1999). The antagonistic actions of TNSALP and NPP1 are now known to be critical in determining the local $\mathrm{PP}_{\mathrm{i}}$ and $\mathrm{P}_{\mathrm{i}}$ levels and, as a result, the levels of bone mineralisation (Johnson et al. 2000, Harmey et al. 2004).

\section{PHOSPHO1}

Another phosphatase critical for bone mineralisation is PHOSPHO1.Thisenzymehydrolyses phosphoethanolamine and phosphocholine to release $P_{i}$ and is thought to contribute to the initiation of mineralisation (Houston et al. 2004, Roberts et al. 2007). Consistent with this role, PHOSPHO1 knockout mice display reduced skeletal mineralisation, growth plate abnormalities and spinal deformities (Yadav et al. 2011, Dillon et al. 2019). Interestingly, deletion for both PHOSPHO1 and TNSALP results in mice with an entirely unmineralised skeleton, further highlighting the pivotal roles of both enzymes in regulating mineralisation (Yadav et al. 2011).

\section{Non-collagenous proteins (NCPs)}

NCPs account for approximately $10 \%$ of the ECM and the majority of them are synthesised by osteoblasts. Many of these proteins can regulate skeletal mineralisation to some extent but of particular importance are matrix gla protein (MGP), osteocalcin (OCN) and osteopontin (OPN). MGP and OCN belong to the gla-containing protein family, members of which require post-translational vitamin K-dependent $\gamma$-carboxylation for activation. MGP acts via gla residues, which have a high affinity for $\mathrm{Ca}^{2+}$, to bind hydroxyapatite and prevent crystal growth (Luo et al. 1997, O'Young et al. 2011). Accordingly, mice lacking MGP display widespread ectopic calcification, particularly in the aorta (Luo et al. 1997).

OCN is highly expressed by mature osteoblasts and is often used as a marker of differentiation. However, its exact role in bone turnover remains unclear. Studies of the first OCN knockout mice reported increased bone mass but no gross skeletal abnormalities (Ducy et al. 1996). More recently it has been suggested that the carboxylated form of OCN is required for binding to hydroxyapatite, whereas uncarboxylated $\mathrm{OCN}$ has an endocrine function, particularly for energy metabolism in bone (Oldknow et al. 2015). Two recent studies have questioned this role, demonstrating that the debate about the exact function of OCN remains ongoing (Diegel et al. 2020, Moriishi \& Komori 2020). 


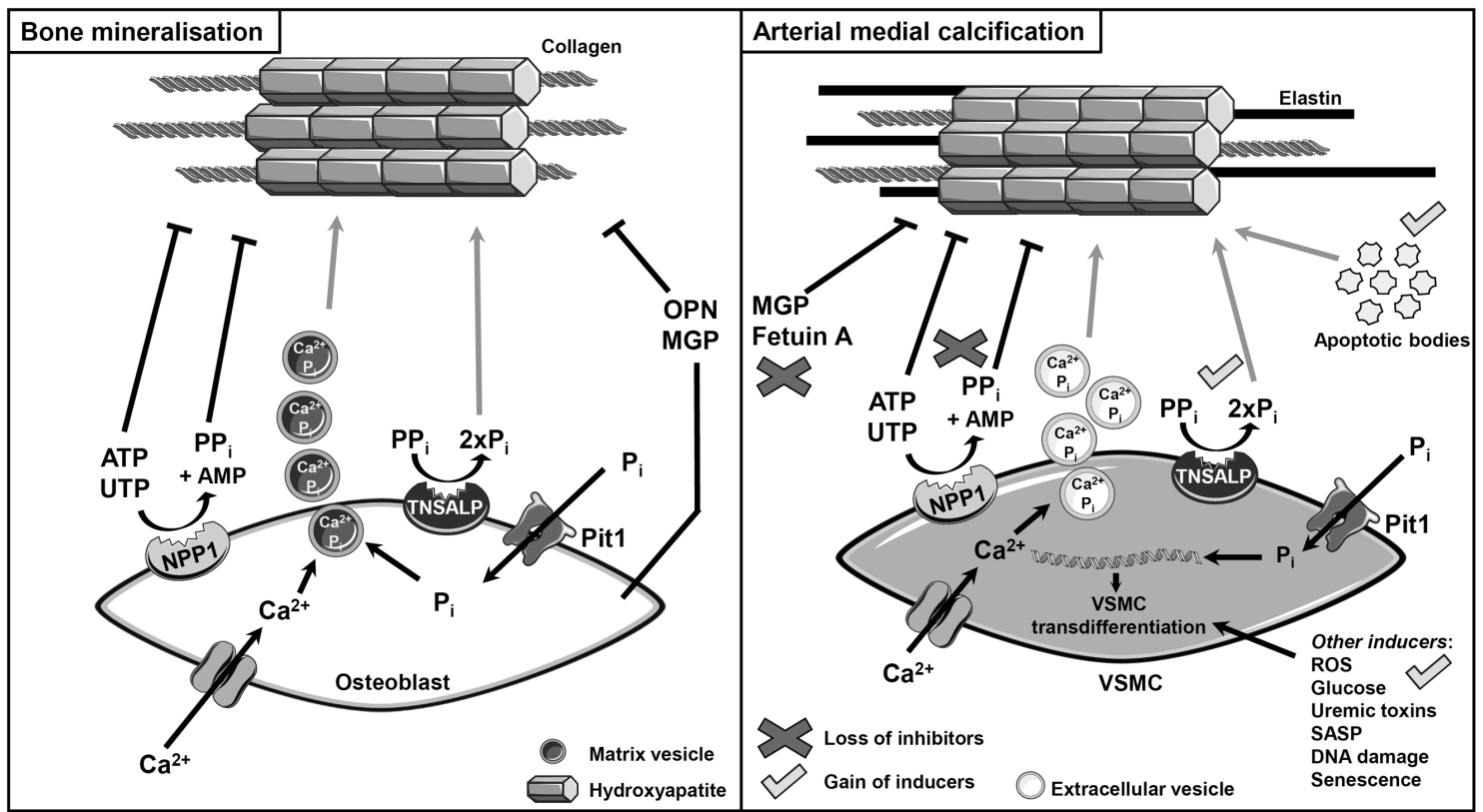

\section{Figure 1}

Comparison of the processes regulating bone formation and AMC. In bone, NPP1 and TNSALP regulate extracellular $\mathrm{P}_{\mathrm{i}} / \mathrm{PP}$ l levels to allow for regulated mineralisation. Osteoblasts also secrete matrix vesicles containing enzymes, $\mathrm{Ca}^{2+}$ and $\mathrm{P}_{\mathrm{i}}$ to facilitate the mineralisation of the deposited osteoid. The processes mediating the development of AMC are multifaceted and involve the loss of calcification inhibitors, gain of calcification inducers, increased apoptosis and VSMC transdifferentiation. Release of mineralisation competent extracellular vesicles may also promote calcification.

OPN, which belongs to the small integrin binding ligand, N-glycosylated (SIBLING) protein family, is also often used as a marker of osteoblast differentiation. OPN contains an acidic serine-rich motif (ASARM) that binds hydroxyapatite and prevents crystal growth (Addison et al. 2010). In keeping with this inhibitory role, OPN knockout mice display increased levels of bone mineral (Boskey et al. 2002).

\section{Extracellular nucleotides}

It is well established that extracellular nucleotides (e.g. ATP, UTP, ADP), signalling via P2 receptors, can modulate osteoblast differentiation, proliferation and function (Orriss 2015). In particular, ATP and UTP act locally to inhibit bone mineralisation and reduce TNSALP expression and activity, effects that are mediated by a number of P2 receptor subtypes (Orriss et al. 2007, 2012, 2013).

\section{Vitamin D}

In its active form vitamin $\mathrm{D}_{3}$ (1,23-dihydroxyvitamin $\left.\mathrm{D}_{3}\right)$, along with parathyroid hormone (PTH) and FGF23, plays a central role in the regulation of $\mathrm{Ca}^{2+}$ and $\mathrm{P}_{\mathrm{i}}$ homeostasis. Acting via its receptor, vitamin $\mathrm{D}_{3}$ directly promotes

\begin{tabular}{|lr} 
https://joe.bioscientifica.com & (c) 2021 Society for Endocrinology \\
https://doi.org/10.1530/JOE-20-0428 & Published by Bioscientifica Ltd. \\
Printed in Great Britain
\end{tabular}

osteoblast differentiation and regulates the expression of proteins including Runx2, OCN and OPN (Price \& Baukol 1980, Prince \& Butler 1987, Gardiner et al. 2000, Drissi et al. 2002). Vitamin $D_{3}$ deficiency is most commonly associated with impaired bone mineralisation leading to rickets in children and osteomalacia in adults.

\section{Ion transporters}

During the mineralisation process, the formation of hydroxyapatite from $\mathrm{Ca}^{2+}$ and $\mathrm{P}_{\mathrm{i}}$ results in the production of $\mathrm{H}^{+}$ions in the ECM that require removal since small reductions in $\mathrm{pH}$ can inhibit the mineralisation process (Brandao-Burch et al. 2005). Chloride-proton antiporters such as CIC3 and CIC5 facilitate $\mathrm{H}^{+}$entry into osteoblasts to remove them from the extracellular environment. Deletion of both ClC3 and CLC5 results in a lack of mineralisation illustrating the importance of chlorideproton exchange in this process (Larrouture et al. 2015).

\section{Vascular calcification}

Vascular calcification is the pathological deposition of calcium phosphate, often as hydroxyapatite, in the 
intimal and/or medial layer of the arteries and the heart valves. It is a common consequence of atherosclerosis, diabetes, chronic kidney disease (CKD) and ageing and is associated with an increased risk of having a future adverse cardiovascular event (e.g. heart attack, stroke) (Zhu et al. 2012). Arterial medial calcification (AMC) refers to the calcification that develops within the tunica media of blood vessels and is characterised by increased vessel stiffness and reduced blood flow. Traditionally, AMC was thought to be a passive process caused solely by high serum levels of $\mathrm{P}_{\mathrm{i}}$ and $\mathrm{Ca}^{2+}$. However, it is now accepted that the development of AMC is a complex, cell-mediated process that is predominantly driven by vascular smooth muscle cells (VSMCs) (Shanahan et al. 2011).

\section{The development of AMC}

The underlying processes which mediate the development of AMC are multifaceted and not fully characterised. Nevertheless, there have been significant advances in our understanding of these in the last few years. Under normal conditions, the actions of local and circulating inhibitors prevent pathological calcification from developing (Zhu et al. 2012, Orriss 2020). However, when the balance between these inhibitors and calcification inducers becomes dysregulated, as occurs in some diseases, mineral deposition can occur. This imbalance can also trigger VSMC transdifferentiation and increased apoptosis. Although a pathological event, the development of AMC is thought to share some similarities with physiological bone formation. As such, many of the enzymes and molecules that regulate bone mineralisation have also been associated with AMC (Fig. 1). These are discussed in more detail below:

\section{Calcification inducers}

Molecules that have been associated with inducing calcification include $\mathrm{Ca}^{2+}, \mathrm{P}_{\mathrm{i}}$, reactive oxygen species (ROS), uremic toxins and glucose (Chen et al. 2006, Byon et al. 2008, Covic et al. 2010, Shanahan et al. 2011). Increased levels of one or more of these inducers can trigger phenotypic changes in VSMCs as well as promote apoptosis. Due to their central role in AMC, in vitro studies typically use increased $\mathrm{P}_{\mathrm{i}}$ and/or $\mathrm{Ca}^{2+}$ levels to model the changes which occur in VSMCs. Mineralisation competent extracellular vesicles, DNA damage and premature VSMC senescence have also been shown to promote calcification (Reynolds et al. 2004, Liu et al. 2013).

The central role of TNSALP in producing $P_{i}$ and driving bone mineralisation means this enzyme has been an area of interest in the context of AMC. Studies have shown that TNSALP expression increases in a calcifying environment and that enzyme inhibition reduces VSMC calcification (Shioi et al. 1995, Narisawa et al. 2007). Furthermore, overexpression of TNSALP in vivo leads to extensive AMC (Sheen et al. 2015). In contrast, other work has reported that enzyme inhibition has no effect on VSMC calcification (Shroff et al. 2010, Morony et al. 2012, Patel et al. 2019). Additionally, comparative studies have shown that, in vitro, TNSALP activity is up to 100 times lower in calcifying VSMCs than mineralising osteoblasts (Patel et al. 2018, 2019). Despite these conflicting data, in vivo studies have reported beneficial effects of TNSALP inhibitors on AMC; however, these also exerted deleterious actions on bone (Pinkerton et al. 2018, Opdebeeck et al. 2020). Thus, it is clear that targeting TNSALP to treat AMC is not without its complications. Inhibition of PHOSPHO1 also reduces VSMC calcification (Kiffer-Moreira et al. 2013). Nevertheless, given the fundamental role of PHOSPHO1 in bone development inhibiting this enzyme therapeutically may also cause adverse skeletal effects.

\section{Calcification inhibitors}

Numerous proteins and small molecules, many of which also inhibit bone mineralisation, have also been shown to block AMC; these include $\mathrm{PP}_{\mathrm{i}}$, ATP, MGP, sclerostin, fetuin A and osteoprotegerin (OPG) (Luo et al. 1997, Min et al. 2000, Ketteler et al. 2002, Patel et al. 2018, De Mare et al. 2019, Orriss 2020). Global knockout mouse models for MGP and OPG develop extensive AMC, highlighting the importance of these proteins in preventing pathological calcification (Luo et al. 1997, Bucay et al. 1998). Generalised calcification of infancy (GACI) is a disease characterised by widespread medial calcification. GACI is primarily caused by mutations in the Enpp1 gene which results in a loss of NPP1 and, consequently, less extracellular $\mathrm{PP}_{\mathrm{i}}$ (Rutsch et al. 2001). Consistent with the human condition, Enpp $1 \%$ mice display aortic calcification and VSMCs derived from these animals show a greater ability to calcify (Johnson et al. 2005). https://joe.bioscientifica.com https://doi.org/10.1530/JOE-20-0428 (c) 2021 Society for Endocrinology Published by Bioscientifica Ltd.
Printed in Great Britain 


\section{VSMC transdifferentiation: how similar are they to osteoblasts?}

In the early 1990s, several groups demonstrated the expression of osteoblast genes (e.g. OPN, BMP2) in calcified deposits and atherosclerotic plaques (Bostrom et al. 1993, Giachelli et al. 1993). Later, bone-associated proteins were also detected in the calcified arteries of patients with end stage renal disease (Moe et al. 2002, Moe et al. 2003). There are now numerous studies reporting that, in a calcifying environment, VSMCs undergo a transdifferentiation to become more osteoblast-like. Specifically, this is associated with a loss of typical VSMC markers (e.g. SM22 $\alpha, \alpha$ SMA, CALD1) and a gain of osteoblast markers (e.g. Runx2, OPN, TNSALP) (Shioi et al. 1995, Shanahan et al. 1999, Jono et al. 2000, Steitz et al. 2001, Zhu et al. 2011). However, despite these changes the cells may not become as osteoblast-like as is widely thought. A recent in vitro study, which directly compared calcifying VSMCs and osteoblasts, showed that whilst calcifying VSMCs express typical osteoblast genes, the levels were significantly lower than those seen in the mature osteoblast (Patel et al. 2019). Other work has also reported that calcifying VSMCs have a transcriptional profile that is only partially similar to osteoblasts and that calcification can occur without changes to VSMC marker gene expression (Alves et al. 2014). Interestingly, VSMCs cultured on hydroxyapatite without calcifying conditions also display increased expression of Runx 2 and TNSALP (Nahar-Gohad et al. 2015), demonstrating that the matrix on which a cell is grown can also influence phenotype.
In vitro VSMC calcification also differs significantly in morphological appearance to in vitro bone formation (Fig. 2). Osteoblasts are able to secrete large amounts of collagenous matrix which is then mineralised to form large 'trabecular-shaped' bone nodules. In contrast, calcifying VSMCs tend to form small discrete regions of calcification that do not appear to be associated with deposited ECM and instead are often associated with cellular debris (Patel et al. 2019). However, it is also worth noting that in both osteoblast and calcifying VSMC cultures, the use of excessive phosphate levels ( $\geq 5 \mathrm{mM}$ ) results in widespread, non-specific mineral deposition that is not a cell-mediated process (Hortells et al. 2015, Patel et al. 2019).

\section{The role of cell death and senescence in bone formation and AMC}

Physiological bone formation is not associated with significant cell death; instead it is thought that apoptosis only occurs to terminate the bone-forming activity of osteoblasts. Approximately $60-90 \%$ of osteoblasts are estimated to die by apoptosis at the end of the bone remodelling phase (i.e. once bone formation is complete) with many of the remaining cells undergoing a terminal differentiation into an osteocyte (Jilka et al. 2007). Ageing is associated with decreased osteoblast proliferation and bone formation and increased senescence, all of which are thought to contribute to age-associated bone loss (Roholl et al. 1994, Jilka et al. 1996, Yudoh et al. 2001).

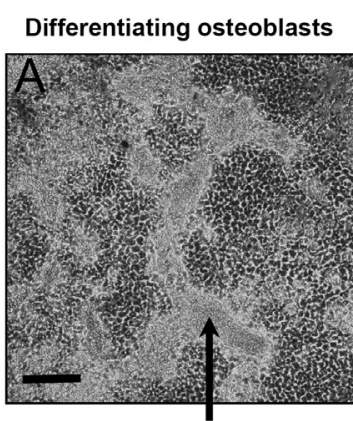

Deposited collagen

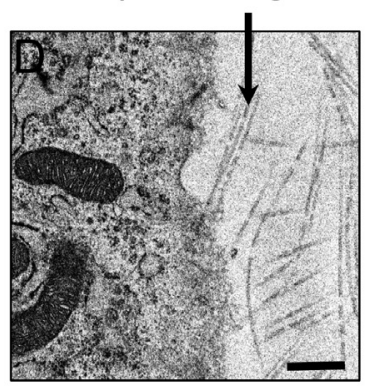

Mature bone-forming osteoblasts

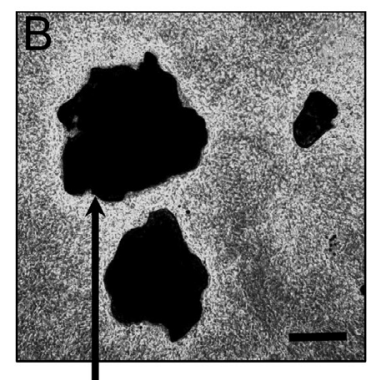

Mineralised bone nodule

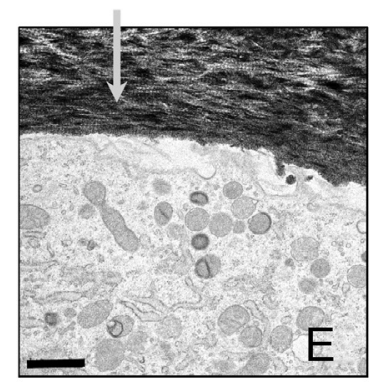

Calcifying VSMCs

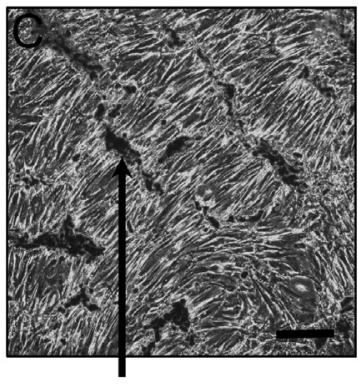

Calcification

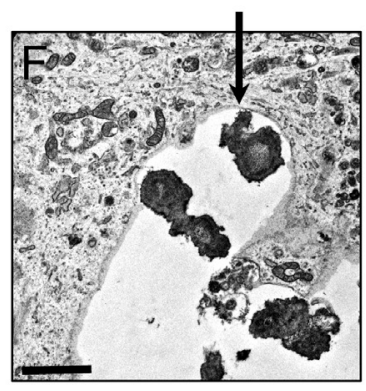

Figure 2

In vitro bone formation and VSMC calcification have different morphological appearances. Phase contrast light microscopy images showing (A) matrix deposition in differentiating osteoblasts and (B) discrete mineralised nodule formation in mature, bone forming osteoblasts. (C) In calcifying VSMCs, regions of calcification are smaller and not obviously associated with deposited matrix. Transmission electron microscopy images show (D) collagen deposition and (E) mineralised matrix in osteoblast cultures. (F) No matrix deposition is apparent in calcifying VSMCs. Scale bars:

$A-C=200 \mu \mathrm{m}, D-E=1 \mu \mathrm{m}, \mathrm{F}=2 \mu \mathrm{m}$. https://joe.bioscientifica.com https://doi.org/10.1530/JOE-20-0428
(C) 2021 Society for Endocrinology Published by Bioscientifica Ltd. Printed in Great Britain 
A number of studies have linked the initiation of AMC with increased VSMC apoptosis (Proudfoot et al. 2000, Clarke et al. 2008, Ciceri et al. 2016). Whilst the mechanisms are not fully characterised, it is thought that a calcifying environment can induce apoptosis and that the VSMC-derived apoptotic bodies act as a nucleation site for calcification (Proudfoot et al. 2000). In agreement, pharmacological inhibition of apoptosis has been shown to decrease VSMC calcification (Ciceri et al. 2016, Patel et al. 2018). AMC is also associated with accumulation of prelamin A, premature senescence and the senescence associated secretory phenotype (SASP) (Liu et al. 2013, Sanchis et al. 2019). In vitro, senescent VSMCs show an increased capacity to calcify, apparently as a result of increased expression of osteoblast marker genes (e.g. Runx2, TNSALP) (Nakano-Kurimoto et al. 2009). However, this seems counter-intuitive given that senescence is associated with decreased TNSALP activity and collagen production in osteoblasts (Kassem et al. 1997). Taken together these findings show that whilst senescence is detrimental to both osteoblasts and VSMCs, the overall end effect of this process differs. Ultimately, it leads to reduced bone formation in the skeleton but increased calcification in the arteries.

\section{The effect of ageing on bone formation and AMC}

An intriguing observation is that AMC and dysregulated bone homeostasis, leading to conditions such as osteoporosis, are diseases of old age. The association between opposing mineralisation processes in ageing was first identified in patients with reduced spinal bone mineral density (BMD) who also presented with AMC (Banks et al. 1994). This phenomenon is also prominent in patients with accelerated ageing diseases such as Werner's syndrome and Hutchinson-Gilford progeria syndrome (HGPS); sufferers of these conditions display increased AMC but reduced BMD (Salamat et al. 2010, Gordon et al. 2011, Pescatore et al. 2019).

Age-related changes are observed in both osteoblasts and VSMCs but to differing effects. In older cells, the capacity to differentiate from MSCs into osteoblasts is reduced and instead the adipogenic lineage is favoured. Ageing is also associated with reduced cell adhesion, bone mineralisation and Wnt expression (Rauner et al. 2008, Coipeau et al. 2009, Lai et al. 2016, Becerikli et al. 2017). In contrast, VSMC ageing is associated with the reverse. Together with switching from a contractile to a synthetic phenotype, increased migration and proliferation, aged VSMCs also demonstrate increased calcification and ECM changes (Bochaton-Piallat et al. 1993, Jiang et al. 2012, Monk \& George 2015). Increased markers of osteogenic differentiation and calcification have also been associated with premature ageing of VSMCs, particularly in children on dialysis or in cells which accumulate prelamin A (Liu et al. 2013, Sanchis et al. 2019). In vivo, rat models of AMC also display more severe calcification and greater changes in VSMC phenotype in aged animals compared to young (Chen et al. 2020).

\section{Bone formation and AMC can be differentially regulated by local and systemic signalling molecules}

The development and maintenance of the skeleton and cardiovascular system are regulated by a vast array of hormones, peptides and local signalling molecules. These can act in an endocrine, paracrine or autocrine manner to directly regulate cell differentiation, function and/ or survival. Many of these have been studied for their effects on bone formation and/or AMC in vitro and in vivo. Importantly, there are now numerous publications describing opposing actions of local and systemic signalling factors on osteoblasts and calcifying VSMCs. Responses of these two cell types to cell and environmental stresses also appear to be different. Some of the signalling systems where differential effects have been reported are discussed below (Fig. 3).

\section{ROS and antioxidants}

The effects of ROS and antioxidants on the bone and the vasculature are well studied. ROS include reactive molecules (e.g. hydrogen peroxide $\left(\mathrm{H}_{2} \mathrm{O}_{2}\right)$ ) and free radicals (e.g. superoxide $\left(\mathrm{O}_{2}{ }^{\cdot}\right)$, hydroxyl $(\mathrm{OH} \cdot)$ ) that oxidise other molecules in order to stabilise themselves. ROS are primarily involved in DNA, mitochondrial and cell damage although these oxidising agents also have beneficial actions such as intracellular signalling and neurotransmitter degradation (Zuo et al. 2015). Antioxidants inhibit the oxidation of these molecules and generally exert beneficial effects on cells. Oxidative stress arises when the levels of ROS exceed those of the endogenous antioxidants, overwhelming the cells' resistance to oxidative damage.

In calcifying VSMCs, different ROS species have been shown to induce VSMC calcification and the expression of 


\begin{tabular}{|c|c|c|}
\hline bone formation and $\mathrm{AMC}$ & bone formation and $\mathrm{AMC}$ & Same effect \\
\hline 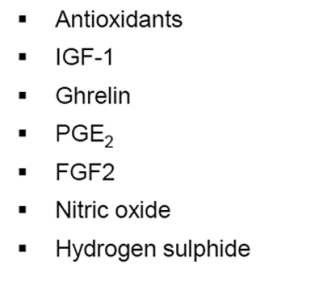 & $\begin{array}{l}\text { - } \text { ROS } \\
\text { - High glucose }\end{array}$ & $\begin{array}{l}\text { Inhibitory: } \\
\text { - } \mathrm{MGP} \\
\text { - } \mathrm{PP}_{\mathrm{i}} \\
\text { - } \mathrm{ATP} / \mathrm{UTP} \\
\text { - Sclerostin } \\
\text { Stimulatory: } \\
\text { - BMP-2 }\end{array}$ \\
\hline $\begin{array}{l}\text { bone formation, effects on } \\
\text { AMC unclear }\end{array}$ & $\begin{array}{l}\text { bone formation, effects on } \\
\text { AMC unclear }\end{array}$ & - Fibronectin \\
\hline $\begin{array}{l}\text { - PTH (intermittent) } \\
\text { - Estrogen / } \\
\text { Testosterone }\end{array}$ & - FGF-23 & \\
\hline
\end{tabular}

\section{Figure 3}

Local and systemic molecules regulating bone formation and AMC. A number of molecules can exert differential effects on bone formation and AMC in vitro and/or in vivo. There are also a number of compounds which exert the same functional effect, be it inhibitory or stimulatory. osteoblast-associated genes and decrease levels of VSMCrelated markers (Mody et al. 2001, Byon et al. 2008, Liu et al. 2014, Sanchis et al. 2019). In contrast, there is good evidence that ROS inhibit osteoblast differentiation and bone formation (Mody et al. 2001, Fatokun et al. 2008, Kim et al. 2010). One of these studies directly compared VSMCs with MC3T3-E1 osteoblast-like cells and found clear differential effects of ROS on VSMC calcification and bone formation (Mody et al. 2001). Thus, much like senescence, the detrimental effects on cell function induced by increased ROS are different in VSMCs and osteoblasts.

In keeping with the beneficial cellular effects of antioxidants, the actions of these compounds on calcifying VSMCs and osteoblasts are also opposing. Numerous studies have reported these differential effects of antioxidants in vitro and in vivo. For example, resveratrol, quercetin, curcumin and allopurinol all reduce VSMC calcification, apoptosis and osteoblast marker gene expression (Hou et al. 2016, Zhang et al. 2016, Cui et al. 2017, Yan et al. 2019). In contrast, these same compounds can increase osteoblast differentiation, TNSALP activity and promote bone formation (Mizutani et al. 1998, Dai et al. 2007, Chen et al. 2016, Orriss et al. 2016, Pang et al. 2018, Son et al. 2018).

Interestingly, a recent paper reported that poly(ADP-ribose) (PAR) plays a key role in driving ECM mineralisation in bone and vascular tissue (Muller et al. 2019). Müller et al. report that PAR production usually occurs in response to DNA damage and oxidative stress and that this signalling pathway can promote osteogenic differentiation (Muller et al. 2019). Numerous studies show that DNA damage promotes the development of AMC (Liu et al. 2013, Sanchis et al. 2019, Bartoli-Leonard et al. 2020) but inhibits bone formation (Kim et al. 2017, da Luz Dias et al. 2018, Qiao et al. 2020, Zhou et al. 2020).
Thus the notion that the beneficial effects of PAR on bone mineralisation are as a result of DNA damage in osteoblasts appears contradictory. However, it is clear that PAR plays an important physiochemical role in driving mineralisation processes and further work is now required to fully reconcile these opposing findings.

\section{PTH, FGF23 and the regulation of $\mathrm{Ca}^{2+}$ and $\mathrm{P}_{\mathrm{i}}$ homeostasis}

The skeleton acts as a major reservoir for the storage of both $\mathrm{Ca}^{2+}$ and $\mathrm{P}_{\mathrm{i}}$. Regulation of blood $\mathrm{Ca}^{2+}$ and $\mathrm{P}_{\mathrm{i}}$ levels is a complex process and involves a number of tissues (bone, kidney, intestine) and hormones (PTH, vitamin $\mathrm{D}_{3}$, FGF23). Dysregulation in this system can have a significant effect on both the bone and the vasculature. $\mathrm{CKD}$, in particular, is associated with hyperphosphatemia and hypocalcaemia leading to the development of AMC and impaired bone turnover (Yamada \& Giachelli 2017).

PTH is secreted by the parathyroid glands in response to low serum $\mathrm{Ca}^{2+}$ levels. It regulates bone remodelling directly via actions on osteoblasts and indirectly by actions in other tissues (such as increasing the formation of active vitamin $\mathrm{D}_{3}$ in the kidney). The effects of PTH on osteoblasts are complex and depend on duration of exposure and the differentiation state of the cells (Isogai et al. 1996). Whilst continuous PTH treatment is catabolic, intermittent PTH treatment stimulates osteoblast differentiation and bone formation, and is used as a treatment for osteoporosis (Qin et al. 2004). PTH can also act on osteoblasts to directly regulate the expression of genes important in bone remodelling (e.g. RANKL, OPG) (Lee \& Lorenzo 1999). The actions of PTH on VSMCs and its role in AMC are less well defined. Although hyperparathyroidisim is associated with AMC and mice with PTH replacement develop aortic calcifications, addition of PTH to VSMCs 
did not alter $\mathrm{Ca}^{2+}$ deposition (Lomashvili et al. 2006, Neves et al. 2007). Thus, it remains unclear whether the effects of PTH on AMC are a consequence of increased $\mathrm{P}_{\mathrm{i}}$ levels or the result of direct actions on VSMCs.

FGF23 is released by osteocytes and osteoblasts in response to high $P_{i}$ levels. It acts in association with its co-factor $\alpha$-klotho to inhibit $P_{i}$ reabsorption in the kidneys. FGF23 knockout mice display hyperphosphatemia, skeletal abnormalities and AMC (Sitara et al. 2004). Equally, mutations in $\alpha$-klotho result in osteoporosis and widespread medial calcification (Kuro-o et al. 1997). Treatment of the osteoblast cell line, MC3T3-E1, with FGF23 and $\alpha$-klotho has been shown to inhibit bone mineralisation (Shalhoub et al. 2011). In agreement, overexpression of FGF23 in osteoblasts can inhibit differentiation and matrix mineralisation (Wang et al. 2008). In contrast, the effects of FGF23 on VSMC calcification are undefined with studies reporting no effects or an increase in calcification (Lindberg et al. 2013, Jimbo et al. 2014). In haemodialysis patients, high FGF-23 levels have been associated with AMC (Turan et al. 2016). Taken together the studies to date suggest that, whilst not fully understood, the direct actions of PTH and FGF23 on osteoblasts and calcifying VSMCs may differ.

\section{Other hormones and local signalling molecules}

Several other signalling molecules and hormones have been shown, albeit in independent studies, to promote osteoblast differentiation and bone formation but inhibit AMC in vitro and/or in vivo. These include IGF-1 (Zhang et al. 2002, Radcliff et al. 2005), ghrelin (Li et al. 2005, Liang et al. 2012), $\mathrm{PGE}_{2}$ (Machwate et al. 2001, Gao et al. 2016), FGF-2 (Canalis et al. 1988, Montero et al. 2000, Borland et al. 2017), nitric oxide (NO) (van't Hof \& Ralston 2001, Kanno et al. 2008) and hydrogen sulphide $\left(\mathrm{H}_{2} \mathrm{~S}\right)$ (Zavaczki et al. 2011, Grassi et al. 2016). In contrast, high glucose levels, as seen in diabetes, inhibit bone formation and increase fracture risk but promote AMC (Chen et al. 2006, Jiao et al. 2015).

The beneficial effects of oestrogen and testosterone on the skeleton are well documented and these actions include stimulating osteoblast differentiation and bone formation (Clarke \& Khosla 2009). In contrast, the influence of these hormones on AMC is less clear since studies have shown both inhibitory (Osako et al. 2010, Son et al. 2010) and stimulatory actions (Balica et al. 1997, Zhu et al. 2016). Thus, further work is required to determine whether oestrogen and testosterone have opposing actions on bone formation and AMC.

\section{The same functional effect, different cellular mechanism}

It is important to acknowledge that not all proteins and signalling molecules exert opposing effects on bone formation and AMC. Molecules including MGP, $\mathrm{PP}_{\mathrm{i}}$, extracellular nucleotides and sclerostin, are inhibitory to both processes (Moe et al. 2005, Patel et al. 2018, De Mare et al. 2019, Orriss 2020) whilst proteins such as fibronectin, BMP-2 and PAR are stimulatory (Ding et al. 2006, Li et al. 2008, Muller et al. 2019). In some cases, the mechanisms mediating these actions are similar; for example, $\mathrm{PP}_{\mathrm{i}}$ acts to directly prevent hydroxyapatite crystal formation and propagation in the same way in any tissue (Orriss 2020). However, the cellular mechanisms mediating these functional effects can also differ. For example, ATP and UTP inhibit both bone mineralisation and VSMC calcification (Orriss et al. 2007, Patel et al. 2018). In osteoblasts, these effects are mediated by multiple P2 receptor subtypes ( $\mathrm{P}_{2} \mathrm{Y}_{2}, \mathrm{P} 2 \mathrm{X} 1$, P2X7) and receptor activation leads to a reduction in TNSALP expression and activity and alterations in endogenous ATP release (Orriss et al. 2007, 2017). In VSMCs, ATP and UTP inhibit VSMC calcification via a reduction in apoptosis (Patel et al. 2018). In contrast, ATP and UTP have no effect on osteoblast survival and so the inhibitory effects of these nucleotides on bone mineralisation do not involve alterations in cell death (Patel et al. 2018).

\section{Conclusions: the calcification paradox}

As discussed, it is established that ageing and diseases can lead to diminished cell function. In osteoblasts, this can result in reduced differentiation and impaired bone formation whereas dysfunctional VSMCs can increase their propensity to calcify leading to AMC development. These cellular changes are reflected systematically by the observation that ageing is associated with an increased risk of developing both AMC and osteoporosis. Furthermore, diseases which cause AMC, such as CKD and diabetes, also induce bone loss and/or abnormalities in bone turnover (Jiao et al. 2015, Neven et al. 2015, Yamada \& Giachelli 2017). Thus, it is important that a treatment for AMC does not induce any further deleterious effects on the bone.

Many of the factors identified here as having opposing effects are anabolic for bone but able to inhibit AMC. Whilst it is acknowledged that very few published 
studies have directly compared the two processes, the evidence overall indicates that it should be feasible to develop a treatment that can prevent or regress AMC without exerting negative actions on the skeleton. Further comparative work is now essential to fully understand these differential actions on osteoblasts and calcifying VSMCs. This will pave the way for developing a bonepreserving therapeutic treatment for AMC.

\section{Declaration of interest}

The authors declare that there is no conflict of interest that could be perceived as prejudicing the impartiality of this review.

\section{Funding}

This work was supported by the British Heart Foundation (grant number: PG15/13/31296) and The Rosetree's Trust (grant number: M744).

\section{References}

Addison WN, Masica DL, Gray JJ \& McKee MD 2010 Phosphorylationdependent inhibition of mineralization by osteopontin ASARM peptides is regulated by PHEX cleavage. Journal of Bone and Mineral Research 25 695-705. (https://doi.org/10.1359/jbmr.090832)

Alves RD, Eijken M, Van De Peppel J \& Van Leeuwen JP 2014 Calcifying vascular smooth muscle cells and osteoblasts: independent cell types exhibiting extracellular matrix and biomineralization-related mimicries. BMC Genomics 15 965. (https://doi.org/10.1186/14712164-15-965)

Anderson HC 1969 Vesicles associated with calcification in the matrix of epiphyseal cartilage. Journal of Cell Biology 41 59-72. (https://doi. org/10.1083/jcb.41.1.59)

Anderson HC 2003 Matrix vesicles and calcification. Current Rheumatology Reports 5 222-226. (https://doi.org/10.1007/s11926003-0071-z)

Balica M, Bostrom K, Shin V, Tillisch K \& Demer LL 1997 Calcifying subpopulation of bovine aortic smooth muscle cells is responsive to 17 beta-estradiol. Circulation 95 1954-1960. (https://doi. org/10.1161/01.cir.95.7.1954)

Banks LM, Lees B, Macsweeney JE \& Stevenson JC 1994 Effect of degenerative spinal and aortic calcification on bone density measurements in post-menopausal women: links between osteoporosis and cardiovascular disease? European Journal of Clinical Investigation 24 813-817. (https://doi.org/10.1111/j.1365-2362.1994.tb02024.x)

Bartoli-Leonard F, Wilkinson FL, Schiro A, Inglott FS, Alexander MY \& Weston R 2020 Loss of SIRT1 in diabetes accelerates DNA damage induced vascular calcification. Cardiovascular Research cvaa134. (https://doi.org/10.1093/cvr/cvaa134)

Becerikli M, Jaurich H, Schira J, Schulte M, Dobele C, Wallner C, Abraham S, Wagner JM, Dadras M, Kneser U, et al. 2017 Agedependent alterations in osteoblast and osteoclast activity in human cancellous bone. Journal of Cellular and Molecular Medicine 21 2773-2781. (https://doi.org/10.1111/jcmm.13192)

Bochaton-Piallat ML, Gabbiani F, Ropraz P \& Gabbiani G 1993 Age influences the replicative activity and the differentiation features of cultured rat aortic smooth muscle cell populations and clones. Arteriosclerosis and Thrombosis 13 1449-1455. (https://doi. org/10.1161/01.atv.13.10.1449)
Bonucci E 1967 Fine structure of early cartilage calcification. Journal of Ultrastructure Research 20 33-50. (https://doi.org/10.1016/s00225320(67)80034-0)

Boonrungsiman S, Gentleman E, Carzaniga R, Evans ND, Mccomb DW, Porter AE \& Stevens MM 2012 The role of intracellular calcium phosphate in osteoblast-mediated bone apatite formation. PNAS 109 14170-14175. (https://doi.org/10.1073/pnas.1208916109)

Borland SJ, Morris TG, Borland SC, Morgan MR, Francis SE, Merry CLR. \& Canfield AE 2017 Regulation of vascular smooth muscle cell calcification by syndecan-4/FGF-2/PKCalpha signalling and cross-talk with TGFbeta. Cardiovascular Research 113 1639-1652. (https://doi. org/10.1093/cvr/cvx178)

Boskey AL 1998 Biomineralization: conflicts, challenges, and opportunities. Journal of Cellular Biochemistry 30-31 83-91. (https:// doi.org/10.1002/(SICI)1097-4644(1998)72:30/31+<83::AIDJCB12>3.0.CO;2-F)

Boskey AL \& Posner AS 1973 Conversion of amorphous calcium phosphate to microcrystalline hydroxyapatite $-\mathrm{pH}$ dependent, solution-mediated, solid-solid conversion. Journal of Physical Chemistry 77 2313-2317.

Boskey AL, Spevak L, Paschalis E, Doty SB \& McKee MD 2002 Osteopontin deficiency increases mineral content and mineral crystallinity in mouse bone. Calcified Tissue International 71 145-154. (https://doi.org/10.1007/s00223-001-1121-z)

Bostrom K, Watson KE, Horn S, Wortham C, Herman IM \& Demer LL 1993 Bone morphogenetic protein expression in human atherosclerotic lesions. Journal of Clinical Investigation 91 1800-1809. (https://doi.org/10.1172/JCI116391)

Brandao-Burch A, Utting JC, Orriss IR \& Arnett TR 2005 Acidosis inhibits bone formation by osteoblasts in vitro by preventing mineralization. Calcified Tissue International 77 167-174. (https://doi.org/10.1007/ s00223-004-0285-8)

Bucay N, Sarosi I, Dunstan CR, Morony S, Tarpley J, Capparelli C, Scully S, Tan HL, Xu W, Lacey DL, et al. 1998 Osteoprotegerindeficient mice develop early onset osteoporosis and arterial calcification. Genes and Development 12 1260-1268. (https://doi. org/10.1101/gad.12.9.1260)

Byon CH, Javed A, Dai Q, Kappes JC, Clemens TL, Darley-Usmar VM, Mcdonald JM \& Chen Y 2008 Oxidative stress induces vascular calcification through modulation of the osteogenic transcription factor Runx2 by AKT signaling. Journal of Biological Chemistry 283 15319-15327. (https://doi.org/10.1074/jbc.M800021200)

Canalis E, Centrella M \& Mccarthy T 1988 Effects of basic fibroblast growth factor on bone formation in vitro. Journal of Clinical Investigation 81 1572-1577. (https://doi.org/10.1172/JCI113490)

Chen NX, Duan D, O'Neill KD \& Moe SM 2006 High glucose increases the expression of Cbfa1 and BMP-2 and enhances the calcification of vascular smooth muscle cells. Nephrology, Dialysis, Transplantation 21 3435-3442. (https://doi.org/10.1093/ndt/gfl429)

Chen Z, Xue J, Shen T, Mu S \& Fu Q 2016 Curcumin alleviates glucocorticoid-induced osteoporosis through the regulation of the Wnt signaling pathway. International Journal of Molecular Medicine $\mathbf{3 7}$ 329-338. (https://doi.org/10.3892/ijmm.2015.2432)

Chen Y, Zhang LS, Ren JL, Zhang YR, Wu N, Jia MZ, Yu YR, Ning ZP, Tang CS \& Qi YF 2020 Intermedin1-53 attenuates aging-associated vascular calcification in rats by upregulating sirtuin 1 . Aging $\mathbf{1 2}$ 5651-5674. (https://doi.org/10.18632/aging.102934)

Ciceri P, Elli F, Braidotti P, Falleni M, Tosi D, Bulfamante G, Block GA \& Cozzolino M 2016 Iron citrate reduces high phosphate-induced vascular calcification by inhibiting apoptosis. Atherosclerosis $\mathbf{2 5 4}$ 93-101. (https://doi.org/10.1016/j.atherosclerosis.2016.09.071)

Clarke BL \& Khosla S 2009 Androgens and bone. Steroids 74 296-305. (https://doi.org/10.1016/j.steroids.2008.10.003)

Clarke MC, Littlewood TD, Figg N, Maguire JJ, Davenport AP, Goddard M \& Bennett MR 2008 Chronic apoptosis of vascular smooth muscle cells accelerates atherosclerosis and promotes calcification and medial https://joe.bioscientifica.com https://doi.org/10.1530/JOE-20-0428 (c) 2021 Society for Endocrinology Published by Bioscientifica Ltd. Printed in Great Britain 
degeneration. Circulation Research 102 1529-1538. (https://doi. org/10.1161/CIRCRESAHA.108.175976)

Coipeau P, Rosset P, Langonne A, Gaillard J, Delorme B, Rico A, Domenech J, Charbord P \& Sensebe L 2009 Impaired differentiation potential of human trabecular bone mesenchymal stromal cells from elderly patients. Cytotherapy 11 584-594. (https://doi. org/10.1080/14653240903079385)

Covic A, Kanbay M, Voroneanu L, Turgut F, Serban DN, Serban IL \& Goldsmith DJ 2010 Vascular calcification in chronic kidney disease. Clinical Science 119 111-121. (https://doi.org/10.1042/CS20090631)

Cui L, Houston DA, Farquharson C \& Macrae VE 2016 Characterisation of matrix vesicles in skeletal and soft tissue mineralisation. Bone $\mathbf{8 7}$ 147-158. (https://doi.org/10.1016/j.bone.2016.04.007)

Cui L, Li Z, Chang X, Cong G \& Hao L 2017 Quercetin attenuates vascular calcification by inhibiting oxidative stress and mitochondrial fission. Vascular Pharmacology 88 21-29. (https://doi.org/10.1016/j. vph.2016.11.006)

da Luz Dias R, Basso B, Donadio MVF, Pujol FV, Bartrons R, Haute GV, Gassen RB, Bregolin HD, Krause G, Viau C, et al. 2018 Leucine reduces the proliferation of MC3T3-E1 cells through DNA damage and cell senescence. Toxicology In Vitro 48 1-10. (https://doi.org/10.1016/j. tiv.2017.12.015)

Dai Z, Li Y, Quarles LD, Song T, Pan W, Zhou H \& Xiao Z 2007 Resveratrol enhances proliferation and osteoblastic differentiation in human mesenchymal stem cells via ER-dependent ERK1/2 activation. Phytomedicine 14 806-814. (https://doi.org/10.1016/j. phymed.2007.04.003)

De Mare A, Maudsley S, Azmi A, Hendrickx JO, Opdebeeck B, Neven E, D'Haese PC \& Verhulst A 2019 Sclerostin as regulatory molecule in vascular media calcification and the bone-vascular axis. Toxins $\mathbf{1 1}$ 428. (https://doi.org/10.3390/toxins11070428)

Dey A, Bomans PH, Muller FA, Will J, Frederik PM, De With G \& Sommerdijk NA 2010 The role of prenucleation clusters in surfaceinduced calcium phosphate crystallization. Nature Materials 9 1010-1014. (https://doi.org/10.1038/nmat2900)

Diegel CR, Hann S, Ayturk UM, Hu JCW, Lim KE, Droscha CJ, Madaj ZB, Foxa GE, Iizaguirre I, Transgenics Core VVA, et al. 2020 An osteocalcin-deficient mouse strain without endocrine abnormalities. PLoS Genetics 16 e1008361. (https://doi.org/10.1371/journal. pgen.1008361)

Dillon S, Staines KA, Millan JL \& Farquharson C 2019 How to build a bone: PHOSPHO1, biomineralization, and beyond. JBMR Plus 3 e10202. (https://doi.org/10.1002/jbm4.10202)

Ding HT, Wang CG, Zhang TL. \& Wang K 2006 Fibronectin enhances in vitro vascular calcification by promoting osteoblastic differentiation of vascular smooth muscle cells via ERK pathway. Journal of Cellular Biochemistry 99 1343-1352. (https://doi.org/10.1002/jcb.20999)

Drissi H, Pouliot A, Koolloos C, Stein JL, Lian JB, Stein GS \& Van Wijnen AJ 2002 1,25-(OH)2-vitamin D3 suppresses the bone-related Runx2/Cbfa1 gene promoter. Experimental Cell Research 274 323-333. (https://doi.org/10.1006/excr.2002.5474)

Ducy P, Desbois C, Boyce B, Pinero G, Story B, Dunstan C, Smith E, Bonadio J, Goldstein S, Gundberg C, et al. 1996 Increased bone formation in osteocalcin-deficient mice. Nature 382 448-452. (https:// doi.org/10.1038/382448a0)

Dudley HR \& Spiro D 1961 The fine structure of bone cells. Journal of Biophysical and Biochemical Cytology 11 627-649. (https://doi. org/10.1083/jcb.11.3.627)

Fatokun AA, Stone TW \& Smith RA 2008 Responses of differentiated MC3T3-E1 osteoblast-like cells to reactive oxygen species. European Journal of Pharmacology 587 35-41. (https://doi.org/10.1016/j. ejphar.2008.03.024)

Fedde KN, Blair L, Silverstein J, Coburn SP, Ryan LM, Weinstein RS, Waymire K, Narisawa S, Millan JL, Macgregor GR, et al. 1999 Alkaline phosphatase knock-out mice recapitulate the metabolic and skeletal defects of infantile hypophosphatasia. Journal of Bone and Mineral Research 14 2015-2026. (https://doi.org/10.1359/ jbmr.1999.14.12.2015)

Fleisch H \& Bisaz S 1962a Isolation from urine of pyrophosphate, a calcification inhibitor. American Journal of Physiology 203 671-675. (https://doi.org/10.1152/ajplegacy.1962.203.4.671)

Fleisch H \& Bisaz S 1962b Mechanism of calcification: inhibitory role of pyrophosphate. Nature 195 911. (https://doi.org/10.1038/195911a0)

Fleisch H, Maerki J \& Russell RG 1966 Effect of pyrophosphate on dissolution of hydroxyapatite and its possible importance in calcium homeostasis. Proceedings of the Society for Experimental Biology and Medicine 122 317-320. (https://doi.org/10.3181/00379727-122-31123)

Gao C, Fu Y, Li Y, Zhang X, Zhang L, Yu F, Xu SS, Xu Q, Zhu Y, Guan Y, et al. 2016 Microsomal prostaglandin E synthase-1-derived PGE2 inhibits vascular smooth muscle cell calcification. Arteriosclerosis, Thrombosis, and Vascular Biology 36 108-121. (https://doi.org/10.1161/ ATVBAHA.115.306642)

Gardiner EM, Baldock PA, Thomas GP, Sims NA, Henderson NK, Hollis B, White CP, Sunn KL, Morrison NA, Walsh WR, et al. 2000 Increased formation and decreased resorption of bone in mice with elevated vitamin D receptor in mature cells of the osteoblastic lineage. FASEB Journal 14 1908-1916. (https://doi.org/10.1096/fj.99-1075com)

Giachelli CM, Bae N, Almeida M, Denhardt DT, Alpers CE \& Schwartz SM 1993 Osteopontin is elevated during neointima formation in rat arteries and is a novel component of human atherosclerotic plaques. Journal of Clinical Investigation 92 1686-1696. (https://doi. org/10.1172/JCI116755)

Gordon CM, Gordon LB, Snyder BD, Nazarian A, Quinn N, Huh S, Giobbie-Hurder A, Neuberg D, Cleveland R, Kleinman M, et al. 2011 Hutchinson-Gilford progeria is a skeletal dysplasia. Journal of Bone and Mineral Research 26 1670-1679. (https://doi.org/10.1002/jbmr.392)

Grassi F, Tyagi AM, Calvert JW, Gambari L, Walker LD, Yu M, Robinson J, Li JY, Lisignoli G, Vaccaro C, et al. 2016 Hydrogen sulfide is a novel regulator of bone formation implicated in the bone loss induced by estrogen deficiency. Journal of Bone and Mineral Research 31 949-963. (https://doi.org/10.1002/jbmr.2757)

Hajjawi MO, Macrae VE, Huesa C, Boyde A, Millan JL, Arnett TR \& Orriss IR 2014 Mineralisation of collagen rich soft tissues and osteocyte lacunae in Enpp1 mice. Bone 69 139-147. (https://doi. org/10.1016/j.bone.2014.09.016)

Harmey D, Hessle L, Narisawa S, Johnson KA, Terkeltaub R \& Millan JL 2004 Concerted regulation of inorganic pyrophosphate and osteopontin by akp2, enpp1, and ank: an integrated model of the pathogenesis of mineralization disorders. American Journal of Pathology 164 1199-1209. (https://doi.org/10.1016/S0002-9440(10)63208-7)

Hessle L, Johnson KA, Anderson HC, Narisawa S, Sali A, Goding JW, Terkeltaub R \& Millan JL 2002 Tissue-nonspecific alkaline phosphatase and plasma cell membrane glycoprotein-1 are central antagonistic regulators of bone mineralization. PNAS 99 9445-9449. (https://doi.org/10.1073/pnas.142063399)

Hortells L, Sosa C, Millan Á \& Sorribas V 2015 Critical parameters of the in vitro method of vascular smooth muscle cell calcification. PLoS ONE 10 e0141751. (https://doi.org/10.1371/journal.pone.0141751)

Hou M, Song Y, Li Z, Luo C, Ou JS, Yu H, Yan J \& Lu L 2016 Curcumin attenuates osteogenic differentiation and calcification of rat vascular smooth muscle cells. Molecular and Cellular Biochemistry 420 151-160. (https://doi.org/10.1007/s11010-016-2778-y)

Houston B, Stewart AJ \& Farquharson C 2004 PHOSPHO1-A novel phosphatase specifically expressed at sites of mineralisation in bone and cartilage. Bone 34 629-637. (https://doi.org/10.1016/j. bone.2003.12.023)

Hutcheson JD, Blaser MC \& Aikawa E 2017 Giving calcification its due: recognition of a diverse disease: a first attempt to standardize the field. Circulation Research 120 270-273. (https://doi.org/10.1161/ CIRCRESAHA.116.310060)

Isogai Y, Akatsu T, Ishizuya T, Yamaguchi A, Hori M, Takahashi N \& Suda T 1996 Parathyroid hormone regulates osteoblast differentiation https://joe.bioscientifica.com

https://doi.org/10.1530/JOE-20-0428 (c) 2021 Society for Endocrinology Published by Bioscientifica Ltd. Printed in Great Britain 
positively or negatively depending on the differentiation stages. Journal of Bone and Mineral Research 11 1384-1393. (https://doi. org/10.1002/jbmr.5650111003)

Jiang L, Zhang J, Monticone RE, Telljohann R, Wu J, Wang M \& Lakatta EG 2012 Calpain-1 regulation of matrix metalloproteinase 2 activity in vascular smooth muscle cells facilitates age-associated aortic wall calcification and fibrosis. Hypertension 60 1192-1199. (https://doi.org/10.1161/HYPERTENSIONAHA.112.196840)

Jiao H, Xiao E \& Graves DT 2015 Diabetes and its effect on bone and fracture healing. Current Osteoporosis Reports 13 327-335. (https://doi. org/10.1007/s11914-015-0286-8)

Jilka RL, Weinstein RS, Takahashi K, Parfitt AM \& Manolagas SC 1996 Linkage of decreased bone mass with impaired osteoblastogenesis in a murine model of accelerated senescence. Journal of Clinical Investigation 97 1732-1740. (https://doi.org/10.1172/JCI118600)

Jilka RL, Weinstein RS, Parfitt AM \& Manolagas SC 2007 Quantifying osteoblast and osteocyte apoptosis: challenges and rewards. Journal of Bone and Mineral Research 22 1492-1501. (https://doi.org/10.1359/ jbmr.070518)

Jimbo R, Kawakami-Mori F, Mu S, Hirohama D, Majtan B, Shimizu Y, Yatomi Y, Fukumoto S, Fujita T \& Shimosawa T 2014 Fibroblast growth factor 23 accelerates phosphate-induced vascular calcification in the absence of klotho deficiency. Kidney International $\mathbf{8 5}$ 1103-1111. (https://doi.org/10.1038/ki.2013.332)

Johnson KA, Hessle L, Vaingankar S, Wennberg C, Mauro S, Narisawa S, Goding JW, Sano K, Millan JL. \& Terkeltaub R 2000 Osteoblast tissue-nonspecific alkaline phosphatase antagonizes and regulates PC-1. American Journal of Physiology: Regulatory, Integrative and Comparative Physiology 279 R1365-R1377. (https://doi.org/10.1152/ ajpregu.2000.279.4.R1365)

Johnson K, Goding J, Van Etten D, Sali A, Hu SI, Farley D, Krug H, Hessle L, Millan JL \& Terkeltaub R 2003 Linked deficiencies in extracellular PP(i) and osteopontin mediate pathologic calcification associated with defective PC-1 and ANK expression. Journal of Bone and Mineral Research 18 994-1004. (https://doi.org/10.1359/ jbmr.2003.18.6.994)

Johnson K, Polewski M, Van Etten D \& Terkeltaub R 2005 Chondrogenesis mediated by PPi depletion promotes spontaneous aortic calcification in NPP1-/- mice. Arteriosclerosis, Thrombosis, and Vascular Biology 25 686-691. (https://doi.org/10.1161/01. ATV.0000154774.71187.fO)

Jono S, McKee MD, Murry CE, Shioi A, Nishizawa Y, Mori K, Morii H \& Giachelli CM 2000 Phosphate regulation of vascular smooth muscle cell calcification. Circulation Research 87 E10-E17. (https://doi. org/10.1161/01.res.87.7.e10)

Kanno Y, Into T, Lowenstein CJ \& Matsushita K 2008 Nitric oxide regulates vascular calcification by interfering with TGF-signalling. Cardiovascular Research 77 221-230. (https://doi.org/10.1093/cvr/ crm049)

Kassem M, Ankersen L, Eriksen EF, Clark BF \& Rattan SI 1997 Demonstration of cellular aging and senescence in serially passaged long-term cultures of human trabecular osteoblasts. Osteoporosis International 7 514-524. (https://doi.org/10.1007/BF02652556)

Ketteler M, Vermeer C, Wanner C, Westenfeld R, Jahnen-Dechent W \& Floege J 2002 Novel insights into uremic vascular calcification: role of matrix gla protein and alpha-2-Heremans Schmid glycoprotein/fetuin. Blood Purification 20 473-476. (https://doi.org/10.1159/000063554)

Kiffer-Moreira T, Yadav MC, Zhu D, Narisawa S, Sheen C, Stec B, Cosford ND, Dahl R, Farquharson C, Hoylaerts MF, et al. 2013 Pharmacological inhibition of PHOSPHO1 suppresses vascular smooth muscle cell calcification. Journal of Bone and Mineral Research 28 81-91. (https://doi.org/10.1002/jbmr.1733)

Kim WK, Meliton V, Bourquard N, Hahn TJ. \& Parhami F 2010 Hedgehog signaling and osteogenic differentiation in multipotent bone marrow stromal cells are inhibited by oxidative stress. Journal of Cellular Biochemistry 111 1199-1209. (https://doi.org/10.1002/jcb.22846)
Kim HN, Chang J, Shao L, Han L, Iyer S, Manolagas SC, O'Brien CA, Jilka RL, Zhou D \& Almeida M 2017 DNA damage and senescence in osteoprogenitors expressing Osx1 may cause their decrease with age. Aging Cell 16 693-703. (https://doi.org/10.1111/acel.12597)

Kuro-o M, Matsumura Y, Aizawa H, Kawaguchi H, Suga T, Utsugi T, Ohyama Y, Kurabayashi M, Kaname T, Kume E, et al. 1997 Mutation of the mouse klotho gene leads to a syndrome resembling ageing. Nature 390 45-51. (https://doi.org/10.1038/36285)

Lai P, Song Q, Yang C, Li Z, Liu S, Lui B, Li M, Deng H, Cai D, Jin D, et al. 2016 Loss of Rictor with aging in osteoblasts promotes age-related bone loss. Cell Death and Disease 7 e2408. (https://doi.org/10.1038/ cddis.2016.249)

Landis WJ, Song MJ, Leith A, Mcewen L \& Mcewen BF 1993 Mineral and organic matrix interaction in normally calcifying tendon visualized in three dimensions by high-voltage electron microscopic tomography and graphic image reconstruction. Journal of Structural Biology $\mathbf{1 1 0}$ 39-54. (https://doi.org/10.1006/jsbi.1993.1003)

Larrouture QC, Nelson DJ, Robinson LJ, Liu L, Tourkova I, Schlesinger PH \& Blair HC 2015 Chloride-hydrogen antiporters ClC-3 and ClC-5 drive osteoblast mineralization and regulate fine-structure bone patterning in vitro. Physiological Reports 3 e12607. (https://doi. org/10.14814/phy2.12607)

Lee SK \& Lorenzo JA 1999 Parathyroid hormone stimulates TRANCE and inhibits osteoprotegerin messenger ribonucleic acid expression in murine bone marrow cultures: correlation with osteoclast-like cell formation. Endocrinology 140 3552-3561. (https://doi.org/10.1210/ endo.140.8.6887)

Lees S, Prostak KS, Ingle VK \& Kjoller K 1994 The loci of mineral in turkey leg tendon as seen by atomic force microscope and electron microscopy. Calcified Tissue International 55 180-189. (https://doi. org/10.1007/BF00425873)

Li GZ, Jiang W, Zhao J, Pan CS, Cao J, Tang CS \& Chang L 2005 Ghrelin blunted vascular calcification in vivo and in vitro in rats. Regulatory Peptides 129 167-176. (https://doi.org/10.1016/j. regpep.2005.02.015)

Li X, Yang HY \& Giachelli CM 2008 BMP-2 promotes phosphate uptake, phenotypic modulation, and calcification of human vascular smooth muscle cells. Atherosclerosis 199 271-277. (https://doi.org/10.1016/j. atherosclerosis.2007.11.031)

Liang QH, Jiang Y, Zhu X, Cui RR, Liu GY, Liu Y, Wu SS, Liao XB, Xie H, Zhou HD, et al. 2012 Ghrelin attenuates the osteoblastic differentiation of vascular smooth muscle cells through the ERK pathway. PLoS ONE 7 e33126. (https://doi.org/10.1371/journal. pone.0033126)

Lindberg K, Olauson H, Amin R, Ponnusamy A, Goetz R, Taylor RF, Mohammadi M, Canfield A, Kublickiene K \& Larsson TE 2013 Arterial klotho expression and FGF23 effects on vascular calcification and function. PLOS ONE 8 e60658. (https://doi.org/10.1371/journal. pone.0060658)

Liu Y, Drozdov I, Shroff R, Beltran LE \& Shanahan CM 2013 Prelamin A accelerates vascular calcification via activation of the DNA damage response and senescence-associated secretory phenotype in vascular smooth muscle cells. Circulation Research 112 e99-e109. (https://doi. org/10.1161/CIRCRESAHA.111.300543)

Liu H, Li X, Qin F \& Huang K 2014 Selenium suppresses oxidative-stressenhanced vascular smooth muscle cell calcification by inhibiting the activation of the PI3K/AKT and ERK signaling pathways and endoplasmic reticulum stress. Journal of Biological Inorganic Chemistry 19 375-388. (https://doi.org/10.1007/s00775-013-1078-1)

Lomashvili K, Garg P \& O’Neill WC 2006 Chemical and hormonal determinants of vascular calcification in vitro. Kidney International 69 1464-1470. (https://doi.org/10.1038/sj.ki.5000297)

Lotsari A, Rajesekharan AK, Halvarsson M \& Andersson M 2018 Transformation of amorphous calcium phosphate to bone-like apatite. Nature Communications 9 4170. (https://doi.org/10.1038/ s41467-018-06570-x) https://joe.bioscientifica.com

https://doi.org/10.1530/JOE-20-0428 (c) 2021 Society for Endocrinology Published by Bioscientifica Ltd. Printed in Great Britain 
Luo G, Ducy P, Mckee MD, Pinero GJ, Loyer E, Behringer RR \& Karsenty G 1997 Spontaneous calcification of arteries and cartilage in mice lacking matrix gla protein. Nature 386 78-81. (https://doi. org/10.1038/386078a0)

Machwate M, Harada S, Leu CT, Seedor G, Labelle M, Gallant M, Hutchins S, Lachance N, Sawyer N, Slipetz D, et al. 2001 Prostaglandin receptor EP(4) mediates the bone anabolic effects of PGE(2). Molecular Pharmacology 60 36-41. (https://doi.org/10.1124/mol.60.1.36)

Mackenzie NC, Zhu D, Milne EM, van't Hof R, Martin A, Darryl Quarles L, Millan JL, Farquharson C \& Macrae VE 2012 Altered bone development and an increase in FGF-23 expression in Enpp1(/-) mice. PLoS ONE 7 e32177. (https://doi.org/10.1371/journal. pone.0032177)

Mahamid J, Sharir A, Addadi L \& Weiner S 2008 Amorphous calcium phosphate is a major component of the forming fin bones of zebrafish: indications for an amorphous precursor phase. PNAS 105 12748-12753. (https://doi.org/10.1073/pnas.0803354105)

Mahamid J, Aichmayer B, Shimoni E, Ziblat R, Li C, Siegel S, Paris O, Fratzl P, Weiner S \& Addadi L 2010 Mapping amorphous calcium phosphate transformation into crystalline mineral from the cell to the bone in zebrafish fin rays. PNAS $\mathbf{1 0 7} 6316-6321$. (https://doi. org/10.1073/pnas.0914218107)

McNally EA, Schwarcz HP, Botton GA \& Arsenault AL 2012 A model for the ultrastructure of bone based on electron microscopy of ion-milled sections. PLOS ONE 7 e29258. (https://doi.org/10.1371/journal. pone.0029258)

McNally E, Nan F, Botton GA \& Schwarcz HP 2013 Scanning transmission electron microscopic tomography of cortical bone using Z-contrast imaging. Micron 49 46-53. (https://doi.org/10.1016/j. micron.2013.03.002)

Millan JL 2013 The role of phosphatases in the initiation of skeletal mineralization. Calcified Tissue International 93 299-306. (https://doi. org/10.1007/s00223-012-9672-8)

Min H, Morony S, Sarosi I, Dunstan CR, Capparelli C, Scully S, Van G, Kaufman S, Kostenuik PJ, Lacey DL, et al. 2000 Osteoprotegerin reverses osteoporosis by inhibiting endosteal osteoclasts and prevents vascular calcification by blocking a process resembling osteoclastogenesis. Journal of Experimental Medicine 192 463-474. (https://doi.org/10.1084/jem.192.4.463)

Mizutani K, Ikeda K, Kawai Y \& Yamori Y 1998 Resveratrol stimulates the proliferation and differentiation of osteoblastic MC3T3-E1 cells. Biochemical and Biophysical Research Communications 253 859-863. (https://doi.org/10.1006/bbrc.1998.9870)

Mody N, Parhami F, Safafian TA \& Demer LL 2001 Oxidative stress modulates osteoblastic differentiation of vascular and bone cells. Free Radical Biology and Medicine 31 509-519. (https://doi.org/10.1016/ s0891-5849(01)00610-4)

Moe SM, O'Neill KD, Duan D, Ahmed S, Chen NX, Leapman SB, Fineberg N \& Kopecky K 2002 Medial artery calcification in ESRD patients is associated with deposition of bone matrix proteins. Kidney International 61 638-647. (https://doi.org/10.1046/j.15231755.2002.00170.x)

Moe SM, Duan D, Doehle BP, O'Neil KD \& Chen NX 2003 Uremia induces the osteoblast differentiation factor $\mathrm{Cbfa} 1$ in human blood vessels. Kidney International 63 1003-1011. (https://doi.org/10.1046/ j.1523-1755.2003.00820.x)

Moe SM, Reslerova M, Ketteler M, O’Neill K, Duan D, Koczman J, Westenfeld R, Jahnen-Dechent W \& Chen NX 2005 Role of calcification inhibitors in the pathogenesis of vascular calcification in chronic kidney disease (CKD). Kidney International 67 2295-2304. (https://doi.org/10.1111/j.1523-1755.2005.00333.x)

Monk BA \& George SJ 2015 The effect of ageing on vascular smooth muscle cell behaviour - a mini-review. Gerontology 61 416-426. (https://doi.org/10.1159/000368576)

Montero A, Okada Y, Tomita M, Ito M, Tsurukami H, Nakamura T, Doetschman T, Coffin JD \& Hurley MM 2000 Disruption of the fibroblast growth factor-2 gene results in decreased bone mass and bone formation. Journal of Clinical Investigation 105 1085-1093. (https://doi.org/10.1172/JCI8641)

Moriishi T \& Komori T 2020 Lack of reproducibility in osteocalcindeficient mice. PLoS Genetics 16 e1008939. (https://doi.org/10.1371/ journal.pgen.1008939)

Morony S, Sage AP, Corbin T, Lu J, Tintut Y \& Demer LL 2012 Enhanced mineralization potential of vascular cells from SM22alpha-Rankl (tg) mice. Calcified Tissue International 91 379-386. (https://doi. org/10.1007/s00223-012-9655-9)

Muller KH, Hayward R, Rajan R, Whitehead M, Cobb AM, Ahmad S, Sun M, Goldberga I, Li R, Bashtanova U, et al. 2019 Poly(ADPribose) links the DNA damage response and biomineralization. Cell Reports 27 3124.e13-3138.e13. (https://doi.org/10.1016/j. celrep.2019.05.038)

Nahar-Gohad P, Gohad N, Tsai CC, Bordia R \& Vyavahare N 2015 Rat aortic smooth muscle cells cultured on hydroxyapatite differentiate into osteoblast-like cells via BMP-2-SMAD-5 pathway. Calcified Tissue International 96 359-369. (https://doi.org/10.1007/s00223-015-9962-z)

Nakano-Kurimoto R, Ikeda K, Uraoka M, Nakagawa Y, Yutaka K, Koide M, Takahashi T, Matoba S, Yamada H, Okigaki M, et al. 2009 Replicative senescence of vascular smooth muscle cells enhances the calcification through initiating the osteoblastic transition. American Journal of Physiology: Heart and Circulatory Physiology 297 H1673-H1684. (https://doi.org/10.1152/ajpheart.00455.2009)

Narisawa S, Frohlander N \& Millan JL 1997 Inactivation of two mouse alkaline phosphatase genes and establishment of a model of infantile hypophosphatasia. Developmental Dynamics 208 432-446. (https://doi.org/10.1002/(SICI)1097-0177(199703)208:3<432::AIDAJA13>3.0.CO;2-1)

Narisawa S, Harmey D, Yadav MC, O'Neill WC, Hoylaerts MF \& Millan JL 2007 Novel inhibitors of alkaline phosphatase suppress vascular smooth muscle cell calcification. Journal of Bone and Mineral Research 22 1700-1710. (https://doi.org/10.1359/jbmr.070714)

Neves KR, Graciolli FG, Dos Reis LM, Graciolli RG, Neves CL, Magalhaes AO, Custodio MR, Batista DG, Jorgetti V \& Moyses RM 2007 Vascular calcification: contribution of parathyroid hormone in renal failure. Kidney International 71 1262-1270. (https://doi. org/10.1038/sj.ki.5002241)

Neven E, Bashir-Dar R, Dams G, Behets GJ, Verhulst A, Elseviers M \& D'Haese PC 2015 Disturbances in bone largely predict aortic calcification in an alternative rat model developed to study both vascular and bone pathology in chronic kidney disease. Journal of Bone and Mineral Research 30 2313-2324. (https://doi.org/10.1002/ jbmr.2585)

Nudelman F, Pieterse K, George A, Bomans PH, Friedrich H, Brylka LJ, Hilbers PA, De With G \& Sommerdijk NA 2010 The role of collagen in bone apatite formation in the presence of hydroxyapatite nucleation inhibitors. Nature Materials 9 1004-1009. (https://doi.org/10.1038/ nmat2875)

Oldknow KJ, Macrae VE \& Farquharson C 2015 Endocrine role of bone: recent and emerging perspectives beyond osteocalcin. Journal of Endocrinology 225 R1-R19. (https://doi.org/10.1530/JOE-14-0584)

Opdebeeck B, Neven E, Millan JL, Pinkerton AB, D'Haese PC \& Verhulst A 2020 Pharmacological TNAP inhibition efficiently inhibits arterial media calcification in a warfarin rat model but deserves careful consideration of potential physiological bone formation/ mineralization impairment. Bone 137 115392. (https://doi. org/10.1016/j.bone.2020.115392)

Orriss IR 2015 The role of purinergic signalling in the musculoskeletal system. Autonomic Neuroscience: Basic and Clinical 191 124-134. (https://doi.org/10.1016/j.autneu.2015.04.013)

Orriss IR 2020 Extracellular pyrophosphate: the body's 'water softener' Bone 134 115243. (https://doi.org/10.1016/j.bone.2020.115243)

Orriss IR, Utting JC, Brandao-Burch A, Colston K, Grubb BR, Burnstock G \& Arnett TR 2007 Extracellular nucleotides block bone mineralization https://joe.bioscientifica.com

https://doi.org/10.1530/JOE-20-0428 (c) 2021 Society for Endocrinology Published by Bioscientifica Ltd. Printed in Great Britain 
in vitro: evidence for dual inhibitory mechanisms involving both P2Y2 receptors and pyrophosphate. Endocrinology 148 4208-4216. (https://doi.org/10.1210/en.2007-0066)

Orriss IR, Key ML, Brandao-Burch A, Patel JJ, Burnstock G \& Arnett TR 2012 The regulation of osteoblast function and bone mineralisation by extracellular nucleotides: the role of P2X receptors. Bone $\mathbf{5 1}$ 389-400. (https://doi.org/10.1016/j.bone.2012.06.013)

Orriss IR, Key ML, Hajjawi MO \& Arnett TR 2013 Extracellular ATP released by osteoblasts is a key local inhibitor of bone mineralisation. PLoS ONE 8 e69057. (https://doi.org/10.1371/journal.pone.0069057)

Orriss IR, Arnett TR, George J \& Witham MD 2016 Allopurinol and oxypurinol promote osteoblast differentiation and increase bone formation. Experimental Cell Research 342 166-174. (https://doi. org/10.1016/j.yexcr.2016.03.004)

Orriss IR, Gueneri D, Hajjawi MOR, Shaw K, Patel JJ \& Arnett TR 2017 Activation of the P2Y2 receptor regulates bone cell function by enhancing ATP release. Journal of Endocrinology 233 341-356. (https:// doi.org/10.1530/JOE-17-0042)

Osako MK, Nakagami H, Koibuchi N, Shimizu H, Nakagami F, Koriyama H, Shimamura M, Miyake T, Rakugi H \& Morishita R 2010 Estrogen inhibits vascular calcification via vascular RANKL system: common mechanism of osteoporosis and vascular calcification. Circulation Research 107 466-475. (https://doi.org/10.1161/ CIRCRESAHA.110.216846)

O’Young J, Liao Y, Xiao Y, Jalkanen J, Lajoie G, Karttunen M, Goldberg HA \& Hunter GK 2011 Matrix gla protein inhibits ectopic calcification by a direct interaction with hydroxyapatite crystals. Journal of the American Chemical Society 133 18406-18412. (https:// doi.org/10.1021/ja207628k)

Pang XG, Cong Y, Bao NR, Li YG \& Zhao JN 2018 Quercetin stimulates bone marrow mesenchymal stem cell differentiation through an estrogen receptor-mediated pathway. BioMed Research International 2018 4178021. (https://doi.org/10.1155/2018/4178021)

Patel JJ, Zhu D, Opdebeeck B, D'Haese P, Millan JL, Bourne LE, WheelerJones CPD, Arnett TR, Macrae VE \& Orriss IR 2018 Inhibition of arterial medial calcification and bone mineralization by extracellular nucleotides: the same functional effect mediated by different cellular mechanisms. Journal of Cellular Physiology 233 3230-3243. (https:// doi.org/10.1002/jcp.26166)

Patel JJ, Bourne LE, Davies BK, Arnett TR, Macrae VE, Wheeler-Jones CP \& Orriss IR 2019 Differing calcification processes in cultured vascular smooth muscle cells and osteoblasts. Experimental Cell Research 380 100-113. (https://doi.org/10.1016/i.yexcr.2019.04.020)

Pescatore LA, Gamarra LF \& Liberman M 2019 Multifaceted mechanisms of vascular calcification in aging. Arteriosclerosis, Thrombosis, and Vascular Biology 39 1307-1316. (https://doi.org/10.1161/ ATVBAHA.118.311576)

Pinkerton AB, Sergienko E, Bravo Y, Dahl R, Ma CT, Sun Q, Jackson MR, Cosford NDP \& Millan JL 2018 Discovery of 5-((5-chloro-2methoxyphenyl)sulfonamido)nicotinamide (SBI-425), a potent and orally bioavailable tissue-nonspecific alkaline phosphatase (TNAP) inhibitor. Bioorganic and Medicinal Chemistry Letters 28 31-34. (https:// doi.org/10.1016/j.bmcl.2017.11.024)

Price PA \& Baukol SA 1980 1,25-Dihydroxyvitamin D3 increases synthesis of the vitamin K-dependent bone protein by osteosarcoma cells. Journal of Biological Chemistry 255 11660-11663.

Prince CW \& Butler WT 1987 1,25-Dihydroxyvitamin D3 regulates the biosynthesis of osteopontin, a bone-derived cell attachment protein, in clonal osteoblast-like osteosarcoma cells. Collagen and Related Research 7 305-313. (https://doi.org/10.1016/s0174-173x(87)80036-5)

Prostak KS \& Lees S 1996 Visualization of crystal-matrix structure. In situ demineralization of mineralized turkey leg tendon and bone. Calcified Tissue International 59 474-479. (https://doi.org/10.1007/BF00369213)

Proudfoot D, Skepper JN, Hegyi L, Bennett MR, Shanahan CM \& Weissberg PL 2000 Apoptosis regulates human vascular calcification in vitro: evidence for initiation of vascular calcification by apoptotic bodies. Circulation Research 87 1055-1062. (https://doi. org/10.1161/01.res.87.11.1055)

Qiao W, Yu S, Sun H, Chen L, Wang R, Wu X, Goltzman D \& Miao D 2020 1,25-Dihydroxyvitamin D insufficiency accelerates age-related bone loss by increasing oxidative stress and cell senescence. American Journal of Translational Research 12 507-518.

Qin L, Raggatt LJ \& Partridge NC 2004 Parathyroid hormone: a doubleedged sword for bone metabolism. Trends in Endocrinology and Metabolism 15 60-65. (https://doi.org/10.1016/j.tem.2004.01.006)

Radcliff K, Tang TB, Lim J, Zhang Z, Abedin M, Demer LL \& Tintut Y 2005 Insulin-like growth factor-I regulates proliferation and osteoblastic differentiation of calcifying vascular cells via extracellular signalregulated protein kinase and phosphatidylinositol 3-kinase pathways. Circulation Research 96 398-400. (https://doi.org/10.1161/01. RES.0000157671.47477.71)

Rauner M, Sipos W \& Pietschmann P 2008 Age-dependent Wnt gene expression in bone and during the course of osteoblast differentiation. Age 30 273-282. (https://doi.org/10.1007/s11357-008-9069-9)

Reynolds JL, Joannides AJ, Skepper JN, Mcnair R, Schurgers LJ, Proudfoot D, Jahnen-Dechent W, Weissberg PL \& Shanahan CM 2004 Human vascular smooth muscle cells undergo vesiclemediated calcification in response to changes in extracellular calcium and phosphate concentrations: a potential mechanism for accelerated vascular calcification in ESRD. Journal of the American Society of Nephrology 15 2857-2867. (https://doi.org/10.1097/01. ASN.0000141960.01035.28)

Roberts S, Narisawa S, Harmey D, Millan JL \& Farquharson C 2007 Functional involvement of PHOSPHO1 in matrix vesicle-mediated skeletal mineralization. Journal of Bone and Mineral Research $\mathbf{2 2}$ 617-627. (https://doi.org/10.1359/jbmr.070108)

Roholl PJ, Blauw E, Zurcher C, Dormans JA \& Theuns HM 1994 Evidence for a diminished maturation of preosteoblasts into osteoblasts during aging in rats: an ultrastructural analysis. Journal of Bone and Mineral Research 9 355-366. (https://doi.org/10.1002/jbmr.5650090310)

Rutsch F, Vaingankar S, Johnson K, Goldfine I, Maddux B, Schauerte P, Kalhoff H, Sano K, Boisvert WA, Superti-Furga A, et al. 2001 PC-1 nucleoside triphosphate pyrophosphohydrolase deficiency in idiopathic infantile arterial calcification. American Journal of Pathology 158 543-554. (https://doi.org/10.1016/S0002-9440(10)63996-X)

Salamat M, Dhar PK, Neagu DL \& Lyon JB 2010 Aortic calcification in a patient with Hutchinson-Gilford progeria syndrome. Pediatric Cardiology 31 925-926. (https://doi.org/10.1007/s00246-010-9711-z)

Sanchis P, Ho CY, Liu Y, Beltran LE, Ahmad S, Jacob AP, Furmanik M, Laycock J, Long DA, Shroff R, et al. 2019 Arterial 'inflammaging' drives vascular calcification in children on dialysis. Kidney International 95 958-972. (https://doi.org/10.1016/j.kint.2018.12.014)

Schwarcz HP, Binkley DM, Luo L \& Grandfield K 2020 A search for apatite crystals in the gap zone of collagen fibrils in bone using dark-field illumination. Bone 135 115304. (https://doi.org/10.1016/j. bone.2020.115304)

Shalhoub V, Ward SC, Sun B, Stevens J, Renshaw L, Hawkins N \& Richards WG 2011 Fibroblast growth factor 23 (FGF23) and alphaklotho stimulate osteoblastic MC3T3.E1 cell proliferation and inhibit mineralization. Calcified Tissue International 89 140-150. (https://doi. org/10.1007/s00223-011-9501-5)

Shanahan CM, Cary NR, Salisbury JR, Proudfoot D, Weissberg PL \& Edmonds ME 1999 Medial localization of mineralization-regulating proteins in association with Mönckeberg's sclerosis: evidence for smooth muscle cell-mediated vascular calcification. Circulation 100 2168-2176. (https://doi.org/10.1161/01.cir.100.21.2168)

Shanahan CM, Crouthamel MH, Kapustin A \& Giachelli CM 2011 Arterial calcification in chronic kidney disease: key roles for calcium and phosphate. Circulation Research 109 697-711. (https://doi. org/10.1161/CIRCRESAHA.110.234914)

Sheen CR, Kuss P, Narisawa S, Yadav MC, Nigro J, Wang W, Chhea TN, Sergienko EA, Kapoor K, Jackson MR, et al. 2015 Pathophysiological https://joe.bioscientifica.com

https://doi.org/10.1530/JOE-20-0428 (c) 2021 Society for Endocrinology Published by Bioscientifica Ltd. Printed in Great Britain 
role of vascular smooth muscle alkaline phosphatase in medial artery calcification. Journal of Bone and Mineral Research 30 824-836. (https:// doi.org/10.1002/jbmr.2420)

Shioi A, Nishizawa Y, Jono S, Koyama H, Hosoi M \& Morii H 1995 Betaglycerophosphate accelerates calcification in cultured bovine vascular smooth muscle cells. Arteriosclerosis, Thrombosis, and Vascular Biology 15 2003-2009. (https://doi.org/10.1161/01.atv.15.11.2003)

Shroff RC, Mcnair R, Skepper JN, Figg N, Schurgers LJ, Deanfield J, Rees L \& Shanahan CM 2010 Chronic mineral dysregulation promotes vascular smooth muscle cell adaptation and extracellular matrix calcification. Journal of the American Society of Nephrology 21 103-112. (https://doi.org/10.1681/ASN.2009060640)

Silver FH \& Landis WJ 2011 Deposition of apatite in mineralizing vertebrate extracellular matrices: a model of possible nucleation sites on type I collagen. Connective Tissue Research 52 242-254. (https://doi. org/10.3109/03008207.2010.551567)

Sitara D, Razzaque MS, Hesse M, Yoganathan S, Taguchi T, Erben RG, Juppner H \& Lanske B 2004 Homozygous ablation of fibroblast growth factor-23 results in hyperphosphatemia and impaired skeletogenesis, and reverses hypophosphatemia in Phex-deficient mice. Matrix Biology 23 421-432. (https://doi.org/10.1016/j. matbio.2004.09.007)

Son BK, Akishita M, Iijima K, Ogawa S, Maemura K, Yu J, Takeyama K, Kato S, Eto M \& Ouchi Y 2010 Androgen receptor-dependent transactivation of growth arrest-specific gene 6 mediates inhibitory effects of testosterone on vascular calcification. Journal of Biological Chemistry 285 7537-7544. (https://doi.org/10.1074/jbc.M109.055087)

Son HE, Kim EJ \& Jang WG 2018 Curcumin induces osteoblast differentiation through mild-endoplasmic reticulum stress-mediated such as BMP2 on osteoblast cells. Life Sciences 193 34-39. (https://doi. org/10.1016/j.lfs.2017.12.008)

Steitz SA, Speer MY, Curinga G, Yang HY, Haynes P, Aebersold R, Schinke T, Karsenty G \& Giachelli CM 2001 Smooth muscle cell phenotypic transition associated with calcification: upregulation of Cbfa1 and downregulation of smooth muscle lineage markers. Circulation Research 89 1147-1154. (https://doi.org/10.1161/ hh2401.101070)

Su X, Sun K, Cui FZ \& Landis WJ 2003 Organization of apatite crystals in human woven bone. Bone 32 150-162. (https://doi.org/10.1016/ s8756-3282(02)00945-6)

Turan MN, Kircelli F, Yaprak M, Sisman AR, Gungor O, Bayraktarolgu S, Ozkahya M, Asci G, Floege J \& Ok E 2016 FGF-23 levels are associated with vascular calcification, but not with atherosclerosis, in hemodialysis patients. International Urology and Nephrology $\mathbf{4 8}$ 609-617. (https://doi.org/10.1007/s11255-016-1231-1)

van't Hof RJ \& Ralston SH 2001 Nitric oxide and bone. Immunology 103 255-261. (https://doi.org/10.1046/j.1365-2567.2001.01261.x)

Wang H, Yoshiko Y, Yamamoto R, Minamizaki T, Kozai K, Tanne K, Aubin JE \& Maeda N 2008 Overexpression of fibroblast growth factor 23 suppresses osteoblast differentiation and matrix mineralization in vitro. Journal of Bone and Mineral Research 23 939-948. (https://doi. org/10.1359/jbmr.080220)

Waymire KG, Mahurnen JD, Jaje JM, Guilarte TR, Coburn SP \& Macgregor GR 1995 Mice lacking tissue non-specific alkaline phosphatase die from seizures due to defective metabolism of vitamin B-6. Nature Genetics 11 45-51. (https://doi.org/10.1038/ng0995-45)
Yadav MC, Simao AM, Narisawa S, Huesa C, Mckee MD, Farquharson C \& Millan JL 2011 Loss of skeletal mineralization by the simultaneous ablation of PHOSPHO1 and alkaline phosphatase function: a unified model of the mechanisms of initiation of skeletal calcification. Journal of Bone and Mineral Research 26 286-297. (https://doi.org/10.1002/ jbmr.195)

Yamada S \& Giachelli CM 2017 Vascular calcification in CKD-MBD: roles for phosphate, FGF23, and klotho. Bone 100 87-93. (https://doi. org/10.1016/j.bone.2016.11.012)

Yan B, Liu D, Zhu J \& Pang X 2019 The effects of hyperuricemia on the differentiation and proliferation of osteoblasts and vascular smooth muscle cells are implicated in the elevated risk of osteopenia and vascular calcification in gout: an in vivo and in vitro analysis. Journal of Cellular Biochemistry 120 19660-19672. (https://doi.org/10.1002/ jcb.29272)

Yudoh K, Matsuno H, Nakazawa F, Katayama R \& Kimura T 2001 Reconstituting telomerase activity using the telomerase catalytic subunit prevents the telomere shorting and replicative senescence in human osteoblasts. Journal of Bone and Mineral Research 16 1453-1464. (https://doi.org/10.1359/jbmr.2001.16.8.1453)

Zavaczki E, Jeney V, Agarwal A, Zarjou A, Oros M, Katko M, Varga Z, Balla G \& Balla J 2011 Hydrogen sulfide inhibits the calcification and osteoblastic differentiation of vascular smooth muscle cells. Kidney International 80 731-739. (https://doi.org/10.1038/ki.2011.212)

Zhang M, Xuan S, Bouxsein ML, Von Stechow D, Akeno N, Faugere MC, Malluche H, Zhao G, en CJ, Efstratiadis A, et al. 2002 Osteoblastspecific knockout of the insulin-like growth factor (IGF) receptor gene reveals an essential role of IGF signaling in bone matrix mineralization. Journal of Biological Chemistry 277 44005-44012. (https://doi.org/10.1074/jbc.M208265200)

Zhang P, Li Y, Du Y, Li G, Wang L \& Zhou F 2016 Resveratrol ameliorated vascular calcification by regulating Sirt-1 and Nrf2. Transplantation Proceedings 48 3378-3386. (https://doi.org/10.1016/j. transproceed.2016.10.023)

Zhou X, Wang Z, Ni Y, Yu Y, Wang G \& CHEN L 2020 Suppression effect of $\mathrm{N}$-acetylcysteine on bone loss in ovariectomized mice. American Journal of Translational Research 12 731-742.

Zhu D, Mackenzie NC, Millan JL, Farquharson C \& Macrae VE 2011 The appearance and modulation of osteocyte marker expression during calcification of vascular smooth muscle cells. PLOS ONE 6 e19595. (https://doi.org/10.1371/journal.pone.0019595)

Zhu D, Mackenzie NC, Farquharson C \& Macrae VE 2012 Mechanisms and clinical consequences of vascular calcification. Frontiers in Endocrinology 3 95. (https://doi.org/10.3389/fendo.2012.00095)

Zhu D, Hadoke PW, Wu J, Vesey AT, Lerman DA, Dweck MR, Newby DE, Smith LB \& Macrae VE 2016 Ablation of the androgen receptor from vascular smooth muscle cells demonstrates a role for testosterone in vascular calcification. Scientific Reports 6 24807. (https://doi. org/10.1038/srep24807)

Zimmermann H, Zebisch M \& Strater N 2012 Cellular function and molecular structure of ecto-nucleotidases. Purinergic Signalling 8 437-502. (https://doi.org/10.1007/s11302-012-9309-4)

Zuo L, Zhou T, Pannell BK, Ziegler AC \& Best TM 2015 Biological and physiological role of reactive oxygen species - the good, the bad and the ugly. Acta Physiologica 214 329-348. (https://doi.org/10.1111/ apha.12515)

Received in final form 11 November 2020

Accepted 16 December 2020

Accepted Manuscript published online 19 December 2020 https://joe.bioscientifica.com https://doi.org/10.1530/JOE-20-0428 (c) 2021 Society for Endocrinology Published by Bioscientifica Ltd. Printed in Great Britain 